\title{
FOUR VERSIONS OF A NEO-ARAMAIC CHILDREN'S STORY
}

\author{
Dr. ELEANOR COGHILL \\ (Universi y of Cambridge)
}

\section{INTRODUCTION}

The texts presented here are four different versions of a children's story passed down the generations orally. The versions vary not only in the actual story, but also in the dialect in which they are recounted, all of which are members of the North-Eastern Neo-Aramaic family (henceforth NENA). It is hoped that the comparison of different versions of one story will give some idea of the variation that oral folktales undergo, and will also facilitate a comparison of the narrative devices used in different dialects.

All versions come from Christian communities ${ }^{1}$ in the NENA area. The first two versions are told respectively in the dialects of the villages of Alqosh ('alquš) and Telkepe (talkepə) ${ }^{2}$ situated in the Mosul Plain in northern Iraq. The third version is told in the dialect of Hamziye (hamziye, also known as hamzik), a village in the Sapna region further north. These versions were recorded by the author during face-to-face interviews with the narrators. The fourth version was recorded in a telephone interview with a lady who was born in the small village of Tazakand (tazäkand) south of Urmia in Iran. Her dialect is related to, but distinct from, standard Christian Urmia.

The story is a children's story. According to the Hamziye speaker, the story is told to children at bedtime to help them sleep. The origins of the story are not known to the author, nor how it travelled from village to village. The four stories are clearly versions of the same story, but show significant variation.

It should be kept in mind that the stories are as recounted on a particular occasion. Unlike written literature, these oral stories have not been fixed in a particular form. Within the same village they might be told differently. They would probably be told somewhat differently by the same person on another occasion or if given more time for preparation. ${ }^{3}$ The stories were not told spontaneously or in the normal context, but in response to a request from the author and with the author as audience. This artificial context seems however

\footnotetext{
1 Chris ians belonging o he Assyrian Church of he Eas or he Chaldean Ca holic Church.

2 Words in bracke $s$ are he names by which hese villages are known in heir own dialec $s$.

3 In fac he Hamziye speaker old her s ory o he au hor a second ime, several years la er, wi h differen wording and de ails, hough wi h he same basic s oryline.
} 
to have had limited impact on the style of storytelling, which is lively and vivid. The two female speakers (Hamziye and Tazakand) seem to be practised storytellers, ${ }^{4}$ though I am not aware if this is the case for the others.

\section{NOTES ON TRANSCRIPTION}

\subsection{Vowels}

The approximate IPA ${ }^{5}$ values of the vowels are as follows:

SHORT VOWELS
$/ a /[\mathfrak{A} \sim 3]$
$/ b /[\mathrm{o}]$ (only Tel., unstressed final vowel)
$/ u /[v]$
$/$ iul $[\mathrm{y}]$ (only Taz.)
$/ \partial /[\vartheta \sim \mathrm{I}]$

LONG VOWELS
$/ \bar{a} /[\mathrm{ar}]$
$/ o /[\mathrm{or}]$
$/ \bar{u} /[\mathrm{uz}]$
$/ \bar{u} /[\mathrm{yz}]$ (only Taz.)
$l e /[\mathrm{ez}]$
$/ i / \quad[\mathrm{i}: \sim \mathrm{i}]$

\subsection{Consonants}

The consonantal symbols have their IPA values, except for the special Semitic symbols (laryngeal', pharyngeals 'and $h$, emphatics $t, s, r$, affricates $c[\mathrm{t}]]$ and $j[\mathrm{~d} z])$. There are some differences in the Tazakand transcription (see $\$ 3.4$ ).

\subsection{Synharmonism}

In Tazakand, as in other dialects of Iranian Azerbaijan, emphasis is a feature covering whole words in many cases. Whole-word emphasis is known as synharmonism. As in dialects such as Christian Sardarid ${ }^{6}$ and Darband ${ }^{7}$, there are two levels of emphasis: middle-timbre and emphatic (pharyngealized/velarized). In middle-timbre words, vowels are backed but there is no pharyngalization. The two levels of emphasis are marked here as follows:

$$
\begin{array}{ll}
{ }^{m} \ldots & \text { middle timbre } \\
+\ldots & \text { emphatic }
\end{array}
$$

In he case of he Tazakand s ory eller, I was made aware of her version by her niece, who had heard $\mathrm{i}$ from her.

5 In ema ional Phone ic Alphabe.

6 Younansardaroud (2001).

7 Au hor's own da a. 


\subsection{Other Symbols}

«...» Small amount of speech deleted due to speaker error.

A...A Arabic.

E... E English.

P...p Persian.

$1 \quad$ Intonation group boundary.

- Nuclear stress of an intonation group.

Minor stress.

\section{THE STORY OF THE SPARROW WITH A THORN IN HIS FOOT: 8 THE FOUR VERSIONS}

\subsection{Alqosh Version 9}

Told by a man in his 30 s, born and raised in Alqosh, now living in London. He heard it from his grandmother in Alqosh.

(1) 'ätwa-w läwa xà-bedika.' jáklà kotwa b-àqlah.'

Once upon a time, there was a sparrow. A thorn got stuck in his foot.

(2) zálla bafyầra,' xzéla ġðà-sota.' 'ämarwa: wó sotò!' nàplațla katwi!!'

He went flying, he saw an old woman. He said, 'Hey, Granny! Take out my thom!'

(3) 'anräwa: hàyyu.' kammapoltầl katwah., kamhalqàla p-tanüra.'

She said, 'Come!' She took out his thorn, she threw it into the oven.

(4) pášla babxầya.' 'ämarwa: 'ú, kában kàtwi!'

He started crying. He said, 'Oh, I want my thorn!'

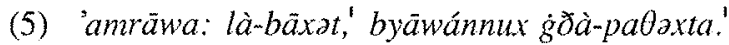

She said, 'Don't cry! I'll give you a piece of bread.'11

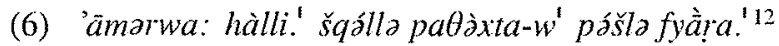

He said, 'Give it to me.' He took the piece of bread and started flying.

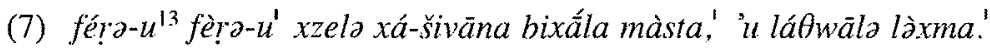

He flew on and on and saw a shepherd eating yoghurt without having any bread.

8 A name given by he au hor of his paper.

${ }^{9}$ For he grammar of his dialec, he reader can refer o he au hor's unpublished PhD hesis (Coghill: 2003).

${ }^{10} j y k \sim c y k \mathrm{I}$ 'o pierce, ge s uck', probably borrowed from Arabic $s k k$ 'o pierce'.

11 A pa0jata is a large hin pi a bread.

12 fyära here is a varian of he progressive form bafyata 'flying", where he b prefix has en irely assimila ed o he ini ial labioden al of he infini ive (fyāra $a * f$ fyära $a<b$ fyära).

${ }^{13}$ No e ha $/ a /$ is regularly elided in ac ual speech before encli ic $"$ 'and': hus $i$ is pro nounced fertl. 
(8) 'āmarwa țālaḥ: wó šivàna!' qấy-iw'at bixāla másta dlà-laxma?'

He said to him, 'O shepherd, why are you eating yoghurt without bread?'

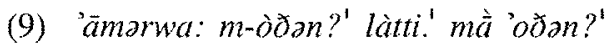

He said, "What should I do? I haven't got any. What should I do?'

(10) 'āmarwa: 'àna byāwánnux pataxta' d-áxlax b-àgðā̇o.' 'āmarwa: hàyyu.' He said, 'T'll give you a piece of bread so that we may eat together.' He said, 'Come.'

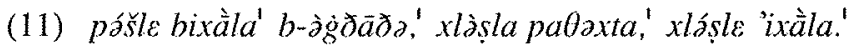
They started eating together. The piece of bread was finished, they finished eating.

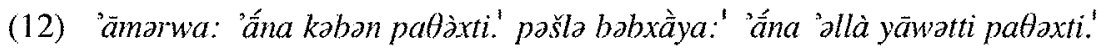
He said, 'I want my piece of bread!' He started crying, 'You must give me my piece of bread.'

(13) 'āmarwa šivăna: là-bāxat!' byāwánnux xà-barāna.'

The shepherd said, 'Don't cry. I'll give you a ram.'

(14) šqállo baràna-w' 'u páśla bofyára fyằra, xzélo gòà-da’wa. ${ }^{14}$

He took the ram and started flying and flying. He saw a wedding party.

(15) xzela nášs wolk tíwa baštà̀ya-w' ${ }^{15}$ látte màzza.'

He saw people who are sitting drinking yet they don't have any appetisers. ${ }^{16}$

(16) 'ämorwa talèy.' yà nās̆a,' qấy-iwotu boštáya dlà-mazza?'

He said to them, 'O people! Why are you drinking without appetisers?'

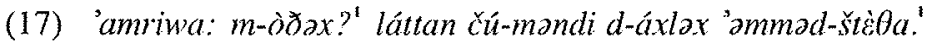

They said, 'What should we do? We don't have anything to eat with the drink.'

(18) 'ämorwa: 'ä́na byāwónnoxu barà̀na.'

He said, 'I'll give you a ram!'

(19) kamyäwálle barấna-w kamnaxrila-u' pášle bixála 'amməd-šțèta.

He gave them the ram and they slaughtered it, and they started eating with the drink.

(20) xlăşle «...» štà̀ya,' 'āmorwa: 'ū, 'ấna kabonni barầni!' "’

They finished drinking. He said, 'Oh I want my ram back!'

(21) póšl bxầya: ${ }^{18^{\prime}}$ 'allá-yãwotüli baràni!!'

He started crying: 'You must give me my ram!'

1 This word, from Arabic dawa, is bonowed in o NENA as da'wa or (wi h he pharyngeal weakened) as da'wa, some imes bo b varians in one dialec.

15 Or tíwa u baštàya w' (unclear).

16 When he ense shif s o he presen in he narra ive, $i$ will be ransla ed here as such, even when $i$ sounds sligh ly awkward in English. This is o draw a en ion o his narra ive device, which will be discussed in $\$ 7.3$ and $\$ 7.5$.

$17 \mathrm{Li}$. 'T wan (for) me my ram back!'

18 = babxäya. As wi h fyarra, he $b$ may assimila e comple ely o he ini ial labial. 
(22) 'amriwa țálaḥ: là-bãxat,' byāwáxlux xáOna-w kà̀lu!'

They said to him, 'Don't cry. We'll give you the bride and groom!'

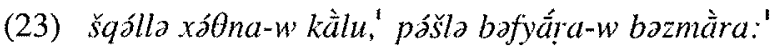

He took the bride and groom, he started flying and singing:

(24) \{chanted rhythmically, with some stressed short vowels becoming long\}

támbal támbal támbaltắ. ${ }^{19} \quad$ Drum drum drum!

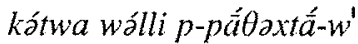

I exchanged a thorn for a piece of bread

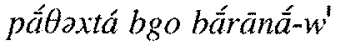

bấräná p-xaOná-w käló

tí tí țìmbaltāa!'

And a piece of bread for a ram

And a ram for a bride and groom

Drrr drrr drum!

\subsection{Telkepe Version ${ }^{20}$}

Told by a man in his $30 \mathrm{~s}$, born and raised in Telkepe, now living in America. He heard it from his father in Telkepe.

(1) xa-butík ${ }^{21}$ wäwa ${ }^{22}$ barxắšs mgandọ̀ว. ${ }^{123}$ xa-butíkp wāwa bgandóra p-šăra", A sparrow was walking, hopping. A sparrow was hopping in the street.

(2) wera kàtwo b-aqle,' zálla gebas-sòtu,' kampaltầla kotwo b-aqle,'

A thorn got into his foot. He went to a little old woman, she got out the thorn in his foot.

(3) kamšaqlà̀lo katwe,' kantalqăla p-tanùra.'

She took his thorn and threw it into the oven.

(4) qàmla butíkp "...»' pašla babxà̀y:' kaban kàtwi,' kabon kàtwi!'

The sparrow «...» started crying. 'I want my thorn, I want my thorn!'

(5) kamamràla:' kamtalqànna p-tanüra!' kamämern: kában kàtwi!' kammewála taxùrtp.'

She said to him, 'I threw it into the oven!' He said to her, 'I want my thorn!' So she gave him a piece of bread. ${ }^{2}$

(6) kamšãqállo taxúrtp zàllo,' borxà̄šp,' xzélo maràyà̀np.'

He took the piece of bread and went off, walking, and he saw a shepherd.

${ }^{19}$ Tambal/tanbalta is derived from Arabic/Persian tabl and refers o a large double sided drum played wi h drums icks. I is played in ou door fes ivi ies, accompanying he zurna or reed pipe.

${ }^{20}$ For he grammar of his dialec, he reader will be able o refer o he au hor's grammar curren ly in prepara ion (Coghill: for hcoming).

21 Bo h Alq. bedika and Tel. butika are borrowed from a Kurdish word for 'sparrow', Cf. he en ry beytik 'sparrow' in Chye (2003).

22 No e ha he usual form of he $3 \mathrm{~ms}$ pas copula in his dialec is wewn.

$23=b+$ mgandor; This verb means 'o roll' or 'o hop'.

2 A laxurla is small hick pi a bread. 


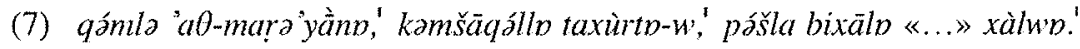
This shepherd got up, he took the piece of bread and they started eating yoghurt.

(8) Xlásla xàlwo' 'ammat-taxúrto-w kùl-mandi.'

They finished the yoghurt, with the piece of bread and everything.

(9) qámla butíkn babxà̀y' mera: kéln taxúrti? kəbən taxùrti!'

The sparrow started crying. He said, "Where is my piece of bread? I want my piece of bread!'

(10) kammämera: kammaxlùxln taxurtux.' kämera: kaban taxiùrti!' kamyāwálla barànn.'

He said to him, 'We ate your piece of bread! [But the sparrow says to him, 'I want my piece of bread!' So he gave him a ram.

(11) kamšãqálla ta barằnn, zálla barxàšs,' xzela ... då wo!'

He took the ram and walked off; he saw a wedding party.

(12) kamšaqlila ta baránp, kamnaxrila.' kanmaxlila-u xláṣla-u zméra mwunàsla.' They took the ram, they slaughtered it, they ate it and it was finished. They sang and enjoyed themselves.

(13) «...» qamla bxéla ta barà̀ne.'

«...» He started crying for his ram.

(14) kamamrila: kamaxlùxla barānux." «...» kămar: kabanni barà̀ni, kaban baràni!'

They said to him, 'We ate your ram.' He says, 'I want my ram! I want my ram!'

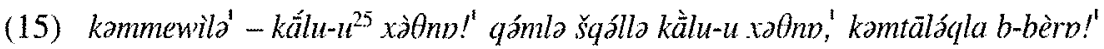
So they gave him the bride and groom! He went and took the bride and groom and threw them into a well!

\subsection{Hamziye Version ${ }^{26}$}

Told by a middle-aged woman who left Hamziye at the age of 4 or 5 , lived in Telkepe for a few years, then moved to Baghdad and later Zakho. She is now living in America. She heard the story from her elder brother, who was told it by their mother.

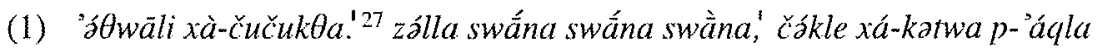
diya.'

I had a female sparrow. She went from roof top ${ }^{28}$ to roof top, and a thorn got stuck in her foot.

${ }^{25}$ No e ha only one $/ u$ / is audible, hough $i$ is presumed ha he par icle $u$ 'and' is presen .

${ }^{26}$ For grammar, G. Kro koff's grammar of Aradhin (1982) is recommended, as i represen $s$ he mos closely rela ed published dialec o da $\mathrm{e}$.

${ }^{27}$ In his dialec $x a$ is he indefini e ar icle for bo h genders. The word $c u c ̌ u k \theta a$ refers o he female of he species, derived from cučukka m. "sparrow'. Cf. no e 99 below for he deriva ion.

28 Swana is ac ually he edge of he roof. 
(2) Oéla morra: tóti tóti ${ }^{29}$ čákle kátwa p- 'àqli.'

She came and said, 'Granny, granny, a thorn has got stuck in my foot.'

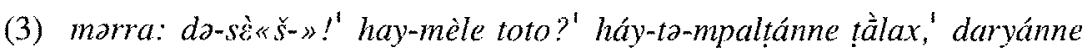
gu tanùra-w,' dắ pyapyánnax xà-laxma.'

She said, 'Get away! Come, what is it, my child? ${ }^{30}$ Come and I'll get it out ${ }^{31}$ for you and put it in the oven. Now l'll bake you a piece of bread. ${ }^{132}$

(4) Oéla tòto,' qanpaltále kátwa m- 'áqlat-čučùk $\theta a$,' 'u qamdaryále gu tanùra,' The old woman came and got out the thorn from the sparrow's foot and put it in the oven.

(5) qamyapyála xa-làxma, '33 'u qəmyawála 'àw-laxma, 'ta d-ày-čučuk $\theta a$ ' Then she baked her a piece of bread and gave the bread to that sparrow.

(6) zálla čučúkta fórra fàrra,' xzéla xà-šivāna.'

The sparrow left, flew on and on, and saw a shepherd.

(7) marra: hăáa! šivàno!' lé 'älot 'axlaxla 'áy-taxarta p-láxma-w xòlya.' marre: yè.'

She said, 'O shepherd, won't you come and eat that piece of bread, with bread and milk?' He said, 'Yes.'

(8) tùle,' xàlle, 'áy-taxórta qamparzíla gu xàlya,' qom 'axlilla, xlòsle.'

They sat down and ate. That piece of bread they crumbled into the milk. They ate it up. ${ }^{3}$

(9) bxéla čučùkta' morra: 'éee! 'äna yóppan láxma diyi,' yoppan taxàrti!' The sparrow burst into tears and said, 'Ahhh, I want my bread! I want my piece of bread!'

(10) morre: là̀ là-baxyat!' hahà̀!' šqúl 'áw-barāna țàlax.'

He said, 'Don't! Don't cry! Hey, take that ram for yourself!'

(11) qámle šivàna, qamyawólle xà-barāna,' ța čučùk $\theta a . '$

The shepherd rose, gave him a ram, that is to the sparrow.

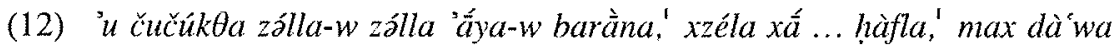
'amraxla.'

So the sparrow went on and on, she and the ram, and saw a party, like a wedding party, let's say. ${ }^{35}$

$29 \mathrm{Li}$. 'my grandmo her', from tota 'grandmo her, old lady' or i s diminu ive form foto 'granny'.

30 Li. 'granny". This is an example of bi polari y in kinship erms, where for ins ance a son calls his fa her 'daddy' and he fa her also calls his son 'daddy'. This is also common in Arabic: see for ins ance Yassin (1977) on Kuwai i Arabic.

$3 \mathrm{Li}$. "ha I may ge i ou .'

$32 \mathrm{Li}$. 'a bread'.

33 In a second elling (several years la er) he speaker used taxarta 'small hick pi a bread' ins ead of he more general laxma

$3 \mathrm{Li}$. 'hey a e $\mathrm{i}$ and finished."

$35 \mathrm{Li}$. 'le 's call i'. 


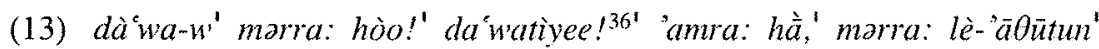
'áwờx hàfla,' 'awờax dà wa',

A wedding party. And she said, 'Hey! Wedding party!' They ${ }^{37}$ say, 'Yes?' She said, 'Won't you all come, so we can hold a party, hold a wedding party?'

(14) 'ắna 'atti 'àw-barxa,' pparmàxle,' ptawðáxle ròzza-w,' šùrba-w', dòlma-w', pàča-w,' ptàxlax,' ptáwơax kèk.'

'I have that lamb. We'll slaughter it and make it into rice and soup and dolma and $p \bar{a} c h a^{38}$ and we'll eat, and we'll make cake.'

(15) morre: yè.' hàyyu!' tùls,' qamparmile 'aw-barxa,' qam 'aw 'oile ràzza-w,' šùrba-w,' prà̀xe-w,' pà̃ca-w,' xálle-w xlàșle,'

They said, 'Yes. Come!' They sat down, slaughtered the lamb, made it into rice and soup and dolma and pacha and ate it up.

(16) ba'dén čučukta bxèla,' marra: 'èee!,' 'āna bấyan barấna dìyi!'

Then the sparrow burst into tears and said, 'Ahhh! I would like my ram!'

(17) marre: 'ù̀!' xlòṣle barāna.' 'axni méka meOáxle baràna?' háyyu hay šqúlle «...» kálow rotna tầlax.'

They said, 'Oh! The ram is finished! From where should we bring a ram? Come and take the bride and groom for yourself.'

(18) qàmla čučuk $\theta a^{\prime}$ šqállāla ${ }^{39}$ kālo-w xàtna-w,' zálla xzéla xà’a,' A 'abu l-zümna.' A 40

The sparrow rose and took the bride and groom. She went on and saw someone, a pipe player.

(19) marra: hòo!' zurnačìyoo!'4l 'ấmor: hà??' 'amra: lé-'ātot 'awðax xa-... dà 'wa?'

She said, 'Hey! Pipe player!' He says, 'Yes?' She says, 'Won't you come so we can make a wedding party?'

(20) 'atti 'ắna kấlo-w xàtna,' 'u 'ắti 'attux zùrna-w' dahòle,' t-awơx hàfla,' t-awðax dà 'wa,' pràqðax' mzàmrax.'

'I have a bride and groom, and you have a pipe and drum, so we can make a party, make a wedding party. We'll dance and sing!'

36 I is no clear o he au hor whe her da watiye f. (cf. Kurdish de'wat wedding) is a synonym of da'wa 'wedding celebra ion', or refers more specifically o he people who are responsible for he fes ivi ies of he wedding. The doubling of he vowel le er here indica es ha $i$ is ex ended: some hing which of en occurs in voca ives in NENA.

37 The agreemen is ac ually feminine singular, wi h da watiye.

38 Pacha is an Iraqi dish: a $s$ ew made from he head of a sheep or from $s$ uffed ripe.

39 śálla la: she ook her 'she ook her', wi h objec agreemen. This form, wi h an ex ra $\mathrm{L}$ suffix marking he pronominal objec on a Qtalle form, is from he Deräbün dialec, he dialec of he informan 's husband and children. The Hamziye form would be he supple ive Qätal form qamšaqläla

"The zurna is ac ually a reed wind ins rumen common in he Middle Eas and radi ionally played a weddings oge her wi h he tambultaldahole, a large drum.

1 The person who plays he zurna (cf. no e 36). 
(21) marre: yé hàyyu!' wádle hăfla,' dà wa,' rqádls zmárre xlàṣlı.'

He said, 'Yes, come!' They held a party, a wedding party and danced and sang, then they finished.

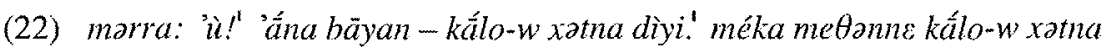
dìax?' xlàslı!'

He said, 'Ohhh! I would like my bride and groom!' 'From where should I bring your bride and groom? They've finished!'

(23) hā, šqúlle 'áwwa - zúrna-w' dahóle ${ }^{42}$ díyi tálax-u sì! !'

'Hey, take this pipe and drum of mine for yourself and go!'

(24) zàlla.' fárra forra fàrra-w, pášla bimära tìn-u' bozmára ta gyà̀na-w.'

She left. She flew on and on and on, and started saying 'ting' and singing to herself:

(25) SSong left out in the original version and inserted from the second telling\}

katwoni p-xa taxàta.' My little thorn for a picce of bread.

taxartá p-xa-baràna.' My piece of bread for a ram.

barāná p-kälo-w xàtna.' A ram for a bride and groom.

kälo-w' xótna p-tambulti.' A bride and groom for my drum.

tambultí qawra mầra.' My drum is calling 'grave'. 4.3

tambultí qawra mà̀ra.' My drum is calling 'grave'.

(26) Mdurqàlla čučuk $\theta a-w '$ npálla-w pqéla-w mòtla.' xlòsla.'

Then the sparrow stumbled, and fell, exploded and died. The end.

\subsection{Tazakand Version 45}

The speaker, around 60 years old, is originally from a small village called Tazakand, SSW of Urmia, on the Baranduz river, close to the mountains dividing Iran from Iraq. ${ }^{46}$ She moved to Tehran in her late teens. Note that the transcription contains some uncertainties, due to the poor quality of the telephone recording and lack of other information on this dialect.

\section{Notes on transcription}

There are some differences in the symbols used in this text. Because of the quality of the recording, it is not possible always to be certain of the exact phonetic reali zation of these sounds. $W$ ' here appears to be IPA $\left[v^{7}\right.$ or possibly $[\beta$ (a bilabial

2 Dahole, from Kurdish dehol, is he same ins rumen as tambaltaltambulta (cf. no e 19).

3 As prose, he syn ax of his would be odd, as here is no copula and he verb comes a he end. Maclean's dic ionary $(1901,2003)$ gives an addi ional meaning for his verb of 'o die suddenly'.

5 For unders anding he grammar of his dialec, works on he rela ed dialec of Chris ian Urmia would be of help, e.g. He zron (1969) and Polo sky (1961), or he dialec of Sardarid (Särdä:rid), ct. Younansardaroud (2001).

6 People of his region are known by he gen ilic erm šăpatnāys.

7 As in Sardarid (Younansardaroud 2001: 4). 
fricative). ${ }^{48}$ The symbol ' $p$ ' represents an unaspirated $\left[p\right.$. As in Urmia ${ }^{49}$ and Sardarid, ${ }^{50}$ there exist two types of affricates: unvoiced $\check{c}[\mathrm{t}]$ and $c[\mathrm{ts}$, and voiced $j[\mathrm{~d} z$ and $j[\mathrm{dz}$. The first of each pair $(\zeta, j)$ are reflexes of original $* k$ or $* g$ respectively. The second

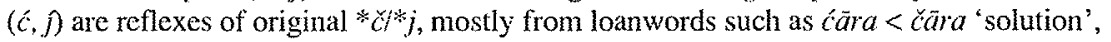
or of * $k * g$ before a high vowel or $/ y /$, e.g. citwa $<$ kitwa 'thorn', jäna $<$ gyäna 'self'.

(1) itta ${ }^{51}$ litta $^{52}$ - xà-siporta itta.' yá sip̀̀rta,' xíšta xdirta,' wírewa ćítwa jo ${ }^{53}$ àqlo.'

There was and there wasn't a certain female sparrow. This sparrow went along, wandered around, and a thom got into her foot.

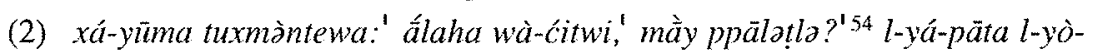
päta...'

One day she thought, 'O God, this thorn of mine. Who will get it out?' To this side and that (she looked)...

(3) xzítewa wélo tónna ${ }^{+}$plàta, $m$-čăwat-xa-bèta.'

She saw there is smoke coming out, from the window ${ }^{55}$ of a house.

(4) xísta xzíta ina xá-dãy sòta,' pyáya làxma.'

She went and she saw, lo and behold there was an old mother, baking bread.

(5) $\bar{a}^{56}$ mirta: mò-payyat ? ${ }^{157}$ mirta: b-ála dày sota, ja- ${ }^{+}$pálaṭlo wà-ćitwi.'

This one said, 'What do you want?' She said, 'Please, ${ }^{58}$ old mother, do take out this thorn of mine.'

«Speaker breaks from story briefly.»

(6) mirtewa ${ }^{59} o$ «...» E $O K{ }^{\mathrm{E}}$ paltànna ćitwa.'

She said, 'Oh, «...» OK. I'll take out the thorn.'

8 As in Darband (au hor's own da a).

9 Cf. He zron (1969: 113) and Odisho (1988: 25).

50 Cf. Younansardaroud (2001: 46). I use her ranscrip ion of $c$ for $\left[\int\right]$ and $c$ for [s].

51 In his dialec, as in Sardarid (Younansardaroud $2001: 4$ ), $/ 7$ is no a phoneme, and words may begin wi h a vowel.

52 <itwa litwa, pas ense of he exis en ial predica or it (neg. lit). The / $w /$ has assimila ed here o he $/ t$.

53 La er in he ex $j o$ is some imes pronounced as $j u$, bu he spelling $j o$ is re ained for con sis ency.

5 The /l/ of he suffix, unusually for NENA, appears o have assimila ed o he preceding / $t /$. here and in lines 5 and 11 , bu wi hou a clearer recording $i$ is no possible o be cer ain.

${ }_{55} \breve{C} a w^{\prime}(<k a \bar{w} w)$ is in fac he radi ional ype of window, a simple hole in he wall, ra her han a modern window.

56 $a$ (<äha) ' his' is probably a borrowing from ano her dialec, Urmia or Sardarid (Younan sardaroud 2001: 180). Elsewhere $y a$ is he feminine near deixis demons ra ives (cf. line 27).

57 Some imes his verb has $/ b /$, like Sardaroud (Younansardaroud 2001: 123); in o her cases i appears o have an unaspira ed / $p /$, like Darband (au hor's own da a).

58 Li . 'by God'.

59. There seems o be some varia ion in he exac form of he $s$ a ive par iciple qtila (f. qtilta) + pas encli ic copula (probably iwa). Some imes he final /al of he par iciple and ini ial $/ i /$ of he copula merge o le/ (qtilewa, qtillewa) and o her imes he /il simply elides (qtílawa. qtillawa). This is some hing ha varies be ween dialec s; i may be ha here is some influence from ano her dialec, perhaps he pres ige Urmia dialec (qull eva), of. He zron (1969: 116), or Sardarid (Younansardaroud 2001: 76). 
(7) Ćitwa püldttawa' rüpíta jo tanǜra.'

She took out the thorn and threw it into the oven.

(8) rïpitawa jo tanü̈ra,' u sipárta xì̌sta.'

She threw it into the oven. And the sparrow went on.

(9) Xíšta xíšta xdírta jríšta xá-yarxa tuxmànta:' äzan šaqlànna ciitwi.'

She went on and on, wandered around, took one month then thought, 'Let me go and get my thom.'

(10) títa mírta qa sòta:' hàllo citwi!!"

She came and said to the old woman, "Give (me) my thom!"

(11) ita bấbi mut ćitwa?' «...» tílax púlotli rūpíli jo tanǜra.'

'Now, my child, ${ }^{60}$ what thorn? «...» You came and I took it out and threw it into the oven.'

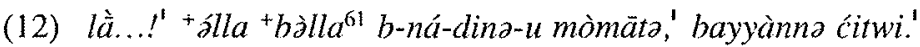

'No, Axby God, Ar by these religions and oaths, I want my thorn.'

(13) ćítwa, qimtewa' mirta: b-ála, ána ćitwa litti. méka ćitwa yawannax?'

The thom. She got up and said, 'By God, I don't have a thorn. From where should I get ${ }^{62}$ you a thorn?'

(14) da-šqúl xá-laxma xùš dardúsar ${ }^{63}$ qāli là-hal.'

'Take a piece of bread and go! Don't give me a headache!'

(15) šquíttewa xà-laxma-w' prìxta xišsta.'

She took a piece of bread and flew on. ${ }^{6}$

(16) príxta xíšta xíšta xdírta xdirta!' +rítewa jo tü̈ränad-dùhuk.'

She flew on and on, and wandered around and around then she glanced (?) in the mountains of Dohuk.

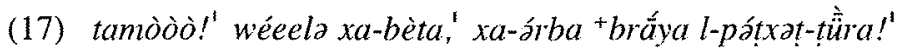

Way over there! There is a house, and a sheep grazing at the foot ${ }^{65}$ of the mountain.

(18) mirtewa b-wó-äla qeman àzan čás-d-ewá.'

She said, 'By that God, let me go ${ }^{66}$ there.'

\footnotetext{
60 Ano her example of bi polari y in kinship erms. Cf. no $e$ 30. Here we have an ex ension of he basic func ion, as he old woman is no even me aphorically he fa her of he spartow. A parallel for his is in he Jilu dialec of NENA, where bäbi is a 'general erm of endearmen, even o a child': cf. he en ry baba in Fox (1997: 126).

61 alla bolla. The empha ic (velarized/pharyngalized) / seems o indica e ha hese are derived from Arabic alläh 'God' and $b$ allăh 'by God', in con ras o he $b$ ala found elsewhere, which has an Aramaic origin.

$62 \mathrm{Li}$. 'give'.

${ }^{63}$ Dardīsar 'headache' is of Persian or Kurdish origin.

6 Li . 'flew, wen'.

$65 \mathrm{Li}$, 'fla ness'.

$66 \mathrm{Li}$. 'le me ge up and go here'. The verb qym I 'o rise, ge up' of en precedes a verb of ac ion: $i$ does no necessarily have o be ransla ed separa ely.
} 
(19) qímta xíš́ta xzìta,' '́na xa- ${ }^{+}$ràyya ${ }^{+}$märù̀ya ${ }^{67}$ arbo.'

She went and saw, lo and behold there was a shepherd grazing sheep.

(20) ina hấdela čpina, masčina,' "boxlấwola àrba,'

Behold, he is so hungry, poor thing, that he is milking the sheep,

(21) u parzúyelo partot-árbo jo 'xàlwa' - 'bxàla.'

and he is crumbling the dung of the sheep into the milk and eating!

(22) mìrtewa qäle68:' fámūni, qa-mú-t hatxa wà̀da?'69

She said to him, 'My dear, ${ }^{70}$ why are you doing this?'

(23) miry: xắti mò odina? ${ }^{171}$ láxxa làxma lit, láxxa bèta lit,' xína màjbür-zn, ${ }^{72}$ järaj d-xà̀yan.'

He said, 'Sister, what should I do? There is no bread here, there is no egg here. After this ${ }^{73}$ I am forced to. I have to live.'

(24) àti pūlàttewa albál laxma yüwálta qù̀le.' mirta: hāna ắna du-ótti ${ }^{74}$ làxma.' šqùl ${ }^{+} x u l !^{\prime}$

This one took it out and straight away gave the bread to him. She said, 'Here you are, ${ }^{75}$ I have bread. Take it and eat!'

(25) b-ála wàhänà har 'mấma čáslo trídawa jo 'xàlwa.'

By God, that one right there in front of her crumbled (bread) into milk.

(26) háda mušč́ra mànno.' láxma trìdawa' $u$ «...» 'xìlewa.'

He thanked her so much. He crumbled the bread into milk and ate it.

(27) ya mádra prìtewa,' $u$ xišta.'

This one again flew off and went away.

(28) xíšta màdro,'xdírta xdírta xdìrta: ' lá-äzan šaqlánno làxmi!'

She went away again and she wandered around and around and around. 'Let me go $^{76}$ and get my bread!'

${ }^{67}<b^{+}$märìya. The $/ b /$ of he preposi ion has assimila ed comple ely o he ini ial $/ \mathrm{m} /$.

68 The $3 \mathrm{~ms}$. pronominal suffix on nouns and preposi ions varies be ween $u$ and $e$ in his ex. This seems o reflec a mixing of dialec s. The form $u$ is usual in he Umia area, while $e$ is found in many o her NENA dialec s.

69 The $b$ found on he infini ive + copula cons ruc ion elsewhere (e.g. bxäla 'ea ing') is absen here, perhaps hrough assimila ion o he labial/w/. Cf. also no e 67 .

${ }^{70} \mathrm{Li}$. 'li le soul', a diminu ive of jäna 'soul'.

71 This appears o be one of he longer 1 sg. qätal (presen) inflec ions: ina (for Ims. an) and äna (for Ifs. $a n$ ). These are found in several o her dialec $s$, such as Mangesh (au hor's own da a).

${ }^{72}$ From Arabic majbür 'forced, compelled'.

${ }^{73}$ The basic meaning of xina is 'o her', bu $i$ has o her meanings, including 'again, af er his; well!' (Maclean 1901, 2003: 8).

${ }^{7} D u$ here may be a deic ic par icle rela ed o he deic ic copula dun $(<d u n)$ 'T am ... righ now".

75 In he sense of French voici.

76 The use of he nega ive $l a+$ subjunc ive presen qälal is similar o English 'shouldn' I ...' wi h an empha ically posi ive meaning, i.e. 'I should'. The falling in ona ion is ha of a $s$ a men ra her han a ques ion. 
(29) títewa l-jánot-wa +ràyyan,' mirewa: xàti u'-ita' äna časlax qa(?) laxma ${ }^{+} x \grave{\partial} l l i{ }^{1}{ }^{+}$blilili.

She came to that same shepherd of ours. He said, 'Sister, well, I ate and swal lowed the bread in front of you!'

(30) méča laxma jo ná türàna?' jo na dấra, tấpə, mèka?'77

'From where (should I get) bread in these mountains, in these valleys ${ }^{78}$ and summits? ${ }^{79}$ From where?'

(31) mírtewa: lá, äna bayyànno laxmi.'

She said, 'No, I want my bread!'

(32) mírewa b-ấla láxma máxma ${ }^{80}$ äna litti. 'cấri àtilo.' xuš šqúllax xa-̀̀rba.' He said, 'By God, bread and the like $I$ don't have it!' 'My solution is this: go and get yourself a sheep!'

(33) qímta ${ }^{81}$ xíšta šquilto xa-árba.'

She went and got herself a sheep.

(34) árba, xấti, lübàlta,' muxdárta muxdárta muxdàrta,'

The sheep, sister, ${ }^{82}$ she took away, and she took it around and around and around.

(35) mirta: ắzan pàrxan' xázan xina eča pxázyan.'

She said, 'Let me go and fly and see where else I will find.'

(36) xíšta xzíta ina wéeela xa- 'mà̀ta,' yấna jo bi-páljat-ṭürầna,' l-óštad-dàra.' She went and saw, behold there is a village way over there. I mean, in the mid dle of the mountains, at the bottom of a valley.

(37) mira: äzan xa-ríša màxyan.' xíšta xzíta ina:'

She said, 'Let me go and check it out. ${ }^{83}$ She went and saw, behold!

liton +bașrat-qanyàno,' ̀ेrbə,' yonằto,' qad ná-mondiyäno 'àxli.'

There is no meat of cows, or of sheep or pigeons, those things which are eaten. ${ }^{8}$

77 The speaker uses wo dialec al varian s here: meča (wi h [ $]$ ) and meka.

${ }^{78} \mathrm{Cf}$. dârầ in Maclean (1901, 2003: 69) 'a valley, glen', from Turkish.

${ }^{79} \mathrm{Cf}$. ta pah in Oraham (1943: 552) 'summi, he op' e c. Also Maclean (1901, 2003: 113) tâpaya " he shoulder of a moun ain".

80 laxma maxma: maxma is an 'echo word' of laxma 'bread'. Echo words beginning in $m$, of en giving a conno a ion of generali $y$ '.. and he like', are found in o her NENA dialec $s$, such as Jewish Azerbaijan (I. Garbell 1965: 82) and Jewish Arbel (G. Khan, 1999: 242). B. Wälchli (2005: 168) men ions he presence in Turkic and Iranian languages, among o hers, of "echo words in which he second par of he compound begins wi h $m$ (of en called $m$ double s).' He gives a Turkish example: Ben doktor moktor değilim 'I am no a doc or or he like.' According o Wälchli (2005: 177), nega ion is 'a favourable con ex for echo words', which is also he con ex in he example here.

${ }^{81}$ Cf. no e 66.

82 Addressing he lis ener, i.e. he au hor of his paper.

${ }^{83} \mathrm{Li}$. 'hi a head', a calque of Persian sar zadan.

$s$ Li. "which hese hings hey ea". 
(39) «...» ina prá́mena xágsa mandiyà̀na,' qad krastyāinüta lè-axlälu.' t-ùp näs̆ə.' xmằrə,' čàlbo,' süsaw'àto.'

Behold, they are slaughtering some things which Christians don't eat. ${ }^{85}$ Even humans. Donkeys, dogs, horses.

(40) mirta: jầnüni, qa-mǘtun hatxa wà̀da?' mä lèna t-xāla!'

She said, 'My dear, why are you doing this? Why, ${ }^{86}$ they are not for eating!'

(41) mírewa: b-àla,' ćấra littan,' qad xàyax xāti.'

They said, 'By God, we don't have any choice, in order to live, sister.'

(42) mírta: ${ }^{87}$ ána itti.' btắzan mayyắna ${ }^{89}$ qālòxun,' ax yamréni, qad 'axlitun răhatat.'

She said, "I have something. ${ }^{88} \mathrm{I}$ 'll go and fetch it for you, as they say, in order for you to eat comfortably.'

(43) xíštewa títa müyíta àrba' yüwàlta qa-ná.'

She went and came and brought the sheep, and gave it to those people. ${ }^{90}$

(44) primewa ax yamri, 'pülìyewa,' bùšlewa,' 'xilewa,' Šòtyewa.'

They slaughtered it, as they say, divided it up, cooked it, ate it and drank.

(45) äti-da wita(?) jo jašnìyu. ${ }^{191}$

This one was also at their feast.

(46) qímta xíšta prìxta.' mrába mannu ax yamri minta tínewa.'

She got up and went ${ }^{92}$ and flew off. Many of them, as they say, thanked her.

(47) príxtewa xišta' - mádry áti jižanta ${ }^{93}$ xišta tuxmànta: 'á ăzan šaqlànno arbi.'

She flew on again that dopey thing went and thought, "Ah, let me go and take my sheep.'

(48) mádro tita l-jánot-na nằ̌s.' mirewa: b-ăla xàtí ät làxxa-twa' axni xilax wo arba.'

Once again she came to those same people. They said, 'By God, sister, you were here. We ate that sheep.'

(49) árba litan.' mùt taxmüna?'

'There is no sheep. What are you thinking?'

(50) w-àla,' +'́lla +bólla ̀̀rba payyanna!' arba payyànna!'

'By God, I want the sheep. I want the sheep!'

85 Li. "which Chris iani y does no ea'.

$86 \mathrm{Li}$. 'Wha!'.

87 Or possibly mirte "she said o hem".

${ }^{88} \mathrm{Li}$. "T have.'

${ }^{89} \mathrm{Cr}$. no e 71 .

$90 \mathrm{Li}$. 'o hese',

91 Or possibly jašniyu, wi h a /j' From Persian jašn 'fes ival, feas ?

92 Or jus 'She wen'. Cf. no e 66.

93 Or possibly gižanta. Cf. gîzhânâ 'dizzy' in Maclean (1901, 2003: 58). 
(51) ät (?) - ná-da mìrewa:' b-ála axni árba mórba ${ }^{95}$ littan.' dút baxzàya.' ina pórya ${ }^{96}$ bnàtz ittan.' éni t-p̧áyyat làballa.'

You (?) these also said, 'By God, sheep and the like we don't have it. You can see! ${ }^{97}$ But we have plenty of girls. Whichever you want, take her!'

(52) mirta: mò btäwəd.'

She said, 'It doesn't matter. 98

(53) qímta šqílta xá-dāna bràta,' u batàya.'

She took one ${ }^{99}$ girl, and was coming along.

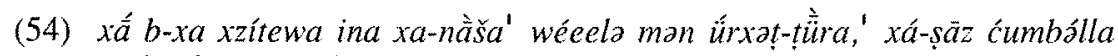
b-jầne.' u bxầ̆sa.'

All of a sudden, she saw, behold there is a person (coming) from the mountain pass, a saz $z^{100}$ slung over himself, going along.

(55) bxầšselə,' al-bál xišta jo sàrre (?).' ${ }^{101}$ mirtewa jánüni èčat bxāša?'

He is going along. Straightaway, she went to meet him (?). She said, "My dear, where are you going?'

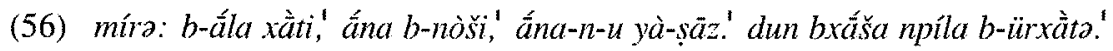
eč̀t 'màtya, ' 'quatța, "mtà̀ma pčālon.'

He said, 'By God, sister, I am by myself. It is me and this saz. I am walking, starting a journey. ${ }^{102}$ Wherever it leads to, finishes, there I will stop.'

(57) mírtewa qà̀le,' xúni yá-șāz hálla qà̀li, yá brāta yawánna qàallux.'

She said to him, 'Brother, give this saz to me and let me give this girl to you.'

(58) míra: b-ắla dáx lattax xầtar.'

He said, 'By God, as you wish.'

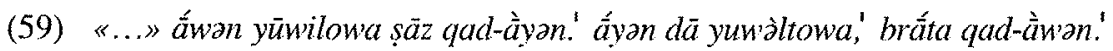

He gave her the saz. She now gave the girl to him.

(60) šquiltewa șàzo,' síqta tǘta jo qarqǘptat-xa-țüra.'

She took her saz, she climbed up and sat on the top of a mountain.

(61) it jayy,', zmirtewa.' mirtewa:' 103

From time to time ${ }^{10}$ she sang:

\{The following was sung by the storyteller:\}

$9 d a$ 'also' is a Turkish loan.

95 Cf. no e 80.

90 Parya is a s a ive par iciple from roo pry. Cf. under pârî in Maclean $(1901,2003: 256)$ and pirr ya 'plen y' in Oraham (1943: 413).

${ }_{97} \mathrm{Li}$. 'you are seeing'.

98 Li. 'Wha will i do?'

99 xá däna bräta: däna is used for enumera ing individual i ems.

${ }^{100}$ A s ringed ins rumen similar o he lu e, wi h a smaller body and longer neck.

lol Jo sarre, if correc, li erally means 'in his head', from Kurdish/Persian sar 'head'.

${ }_{102} \mathrm{Li}$. 'fallen on pa hs'. Cf. Maclean (1901, 2003: 216) for nâpil/ 'urxälb "uxã "o s at on a joumey'.

10. Li . 'she sang, she said'.

to $\mathrm{Li}$. "here are imes". 
(62) Ćitwa yüwalli bod laxma, tongalo șāz țing.

A thom I gave for bread, tongalo săz tang.

(63) laxma yüwalli bad arba, tongala șāz tang.

Bread I gave for a sheep, tongala șàz țang.

(64) arba yüwalli bəd brāta, tongalı șāz tong.

A sheep I gave for a ginl, tongalo șăz ţong.

hátxala áx zmirèli qālax,' mā-da hátxa zmìrtuwa qälu.'

It's like that. As I sang it to you, thus also she sang it to him.

\section{STRUCTURE OF THE STORY}

The common structure to the different versions is as follows:

1. A sparrow gets a thom stuck in its foot.

EP SODE

2. It goes and finds an old woman and asks her to get it out. She gets it out and throws it into her oven.

3. The sparrow starts crying (not in Taz.) and asking for its thorn back.

4. The old woman gives the sparrow a piece of bread instead.

EP SODE

5. The sparrow goes off and meets a shepherd to whom it offers the bread. They eat the bread with yoghurt (Ham./Taz. milk).

6. The sparrow then starts crying (not in Taz.) and wants its bread back.

7. The shepherd gives it a ram (Taz. a sheep).

EP SODE

8. The sparrow goes off and comes upon a wedding party (Taz. a starving village). It shares the ram with the people there.

9. The sparrow then starts crying (not in Taz.) and wants its ram back.

10. The people give the sparrow a bride and groom (Taz. a girl).

EP SODE $\mathrm{V}$

11. (Ham./Taz.) The sparrow goes off and meets a musician (Ham. pipe player, Taz. saz player), and hands over the bride and groom/girl.

12. (Ham.) The sparrow asks for the bride and groom back.

13. (Ham./Taz.) The musician gives the sparrow his pipe and drum/saz in return for the bride and groom/girl.

END NG

14. The ending varies in the different versions, but in three out of the four ver sions the sparrow sings a song (see $\$ 5$ for more).

As can be seen, the story has a repetitive structure with several episodes, each involving a new character. In Alqosh and Telkepe these characters are: the old woman, the shepherd and the people at the wedding party. In Hamziye the pipe-player is added. In Tazakand the wedding party is replaced by a 
starving village and a different musician (a saz-player) is added. Each time the sparrow meets one of these characters it gives or shares something with him or her, then later starts to cry (except in Taz.) and asks for it back. To placate the sparrow, each character gives something in exchange, which the sparrow then goes on to exchange for something else.

\section{VARIATIONS IN THE STORY}

The two versions from the Mosul Plain, Alqosh and Telkepe, are similar with only minor differences. In Telkepe the sparrow hops or walks rather than flies. At the end Alqosh has the sparrow flying off with the bride and groom, chanting a rhyme. Telkepe has the sparrow throwing the bride and groom into a well, and concludes without a rhyme.

The Hamziye version is similar, except for the additional episode. There is merely a little more detail about the wedding party. In the additional episode the sparrow meets a pipe-player and together they hold a wedding party with the bride and groom. When the sparrow demands the bride and groom back, the pipe-player gives her his pipe and drum instead. The sparrow flies off and, as in Alqosh, sings to herself (though the song was not included in the initial telling). In this version alone the sparrow dies at the end.

The Tazakand version is considerably longer and more elaborate than the other three. There are some minor differences: it has an unspecific sheep $(a r b a)$, rather than the ram (baranna) of the other three versions. There is no mention of the sparrow crying at each stage. It also has the sparrow wandering off for quite some time before coming back to reclaim what she has lost. There is generally more description: the smoke from the window of the old woman's house; the shepherd so hungry that he is crumbling dried dung into his milk instead of bread. Later there are some more fundamental differences. The wedding party is replaced by a starving village where the people are eating forbidden meats, and only a girl is given instead of a bride and groom. Like Hamziye it has an additional episode, where the sparrow meets a saz-player and exchanges the girl for the instrument.

As in all versions except Telkepe, ${ }^{105}$ Tazakand ends with a rhyme, sung by the narrator, where the sparrow recounts all the exchanges that have been made. ${ }^{106}$ The inclusion in the Alqosh rhyme of the word tambalta 'drum', just as in Hamziye, suggests that an earlier version of the Alqosh story may also have involved an exchange of the bride and groom for a pipe and drum, as occurs in the Hamziye story.

105 We canno be sure his version did no originally have a rhyme.

106 Cf. Ferguson and Rice (1960) for a discussion of some children's rhymes in Iraqi Arabic, including some ha form par of a s ory. 


\section{VARIATIONS IN THE LANGUAGE}

The dialects of these four versions are quite diverse. Alqosh and Telkepe are relatively closely related dialects, yet there are still quite obvious differences between the two. Hamziye is a little further removed, both geographically and linguistically, while the dialect of the Tazakand version is quite distinct from all the others. There is not space here to go into the many grammatical differences between the four dialects. Of more relevance is the variation in some of the lexical items playing an important role in the story, as in shown in the table below. The dialects are ordered geographically, from south to north. Note that words in \{\} brackets are not actually found in the text but are sourced from other fieldwork and added for completeness.

Main differences in key lexicon

\begin{tabular}{|c|c|c|c|c|}
\hline & Telkepe & Alqosh & Hamziye & Tazakand \\
\hline sparrow & butiko $(\mathrm{K} .)^{107}$ & bedika $(\mathrm{K} .)^{108}$ & 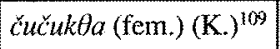 & siparta $($ fem.) (A.) \\
\hline to fly & $\{f y ! \cdot I\}(\text { Arab. })^{110}$ & fyr I (Arab.) & $f y \cdot I($ Arab. $)$ & prx I (A.) \\
\hline to throw away & $\lg \mathrm{I}(\mathrm{A} .)^{111}$ & hlq $\mathrm{II}$ & $\{\tilde{s} y t \mathbf{I}\}$ & rpy II (A.) \\
\hline shepherd & ma!̀ yānv (A.) & šiväna $(\mathrm{K})$. & šivăna $(\mathrm{K})$. & "rayya (A.) \\
\hline yoghurt & $x a l w n($ A.) & $\operatorname{masta}(\mathrm{K})$. & $\{$ masta $\}(\mathrm{K})$. & $?$ \\
\hline milk & $\{x a l y p\}(\text { A. })^{112}$ & $\{x \partial l y a\}(\mathrm{A})$ & $x a l y a(\mathrm{~A})$. & ${ }^{+} x a l w a$ (A.) \\
\hline
\end{tabular}

A.=Aramaic, $K=$ Kurdish, Arab.=Arabic, Pers $=$ =Persian

\section{NARRATIVE DEVICES}

The texts afford a useful opportunity to compare various features of narrative style in NENA folktales.

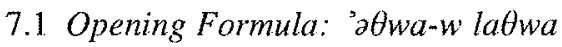

A feature common to many NENA dialects is the formula which begins two of the versions: " $\theta \omega w a-w$ la $\theta w a$ in Alqosh and 'itta litta in the Tazakand version. This means 'there was and there wasn't' and is the standard fairy tale opening, equivalent to 'once upon a time' in English fairytales. This formula

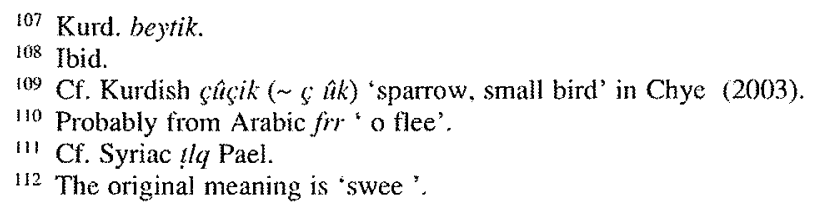


is also found in other Middle Eastern languages: for instance Arabic kän yä mä $k a \bar{n}$ 'there was or there wasn't', Kurdish hebu nebu and Turkish (bir) varmiš (bir) joxmus."113

\subsection{Narrative Tenses: General}

One of the main differences between the versions is to be found in the tenses through which the tale is recounted. In Alqosh, Telkepe and Hamziye, the main narrative tense is the qtollo form ${ }^{114}$ and its equivalent with pronominal object: Alq./Tel. kamqātalla/ Ham. qamqātalle: ${ }^{115}$

(1) jákla katwa b àqlah.' zállo bafyặ̀a,' xzéla ġđà-sota.' A thom got stuck in his foot. He went flying, he saw an old woman. (Alq. 12 )

(2) wera kàtwo b aqle,' zállo gebos sòtu,' kampaltầla katwo b aqle,' A thorn got into his foot. He went to a little old woman, she got out the thorn in his foot. (Tel. 2)

(3) č́skle xá katwa p áqla diya.' Oéla marra: A thorn got stuck in her foot. She came and said (Ham. 12)

In the Tazakand version we find the qtila participle (feminine qtilta) being used as the main narrative tense. In many Assyrian ${ }^{16}$ dialects this stative participle is used with the present copula as a narrative tense. ${ }^{17}$ In a string of successive verbs the copula is sometimes not repeated. But in this text its usage is somewhat different. It is used without any copula from the beginning of a discourse section, as in the following example:

(4) qimta xîsta prìxta.' She got up and went and flew off. (Taz. 46)

This structure - qtila - alternates with another structure: the stative participle plus past copula (qtilewa < qtila $+-i w a)$. This can be seen in the example below, where it is immediately followed by several qtila forms:

(5) príxtewa xišta' mádra ắti jižanta xišta tuxmònta: ... She flew on again that dopey thing went and thought ... (Taz. 47)

There is no obvious difference in the function or distribution of the two forms, qtila and qtilewa, but further investigation is needed.

113 I. Garbell (1965: 175).

11 This name is based on he form wi h he $s$ andard paradigm verb qtl I 'o kill'.

115 In many NENA dialec $s$ qtalls canno ake a full range of pronominal objec affixes. A form based on he presen base qätal, wi h prefix $\mathrm{kam} / \mathrm{qam}$, is used when a pronominal objec is required.

116 T.e. dialec s spoken by members of he Assyrian Church of he Eas, who usually origina $e$ in he nor herly par of he NENA area, especially sou h eas ern Turkey and nor $h$ wes ern Iran.

117 G. Khan (personal communica ion). The dialec of Barwar is one. 


\subsection{Narrative Tenses: The Verb to Say}

An intriguing feature of these texts is their different treatments of the verb 'to say' in narrative. In Alqosh and Telkepe ' $m r$ I 'to say' can be treated like any other verb, i.e. with the qtalla form or its aspectual equivalent kanqätalla: mera 'he said', kam'āmera 'he said to him'. This verb, however, does show a tendency to use alternative forms not otherwise common in narrative.

In Telkepe one of these is kämar. This is the k-qätal form, which is normally used for the (habitual) present, as in kpälax 'he works', kxäza 'he sees'. With the verb ' $n r$ I, however, it can be used as a narrative tense. The use of a present tense in narrative ('historical present') is a common device across many languages and usually serves to make a narrative more vivid to the listener. ${ }^{118}$ It is common, for example, in colloquial English, when telling a story, to say 'and then he says.. then she says..' and so on. The examples of this form in the text are in lines 10 and 14:

(6) kommāmera: kammaxlùxlo taxurtux.' kāmera: kabon taxùrti!' kamyäwállo barànn.' He said to him, 'We ate your piece of bread! [But the sparrow says to him, 'I want my piece of bread!' So he gave him a ran. (Tel. 10)

(7) kamamrila: kamaxlùxla baränux." "...» kấmor: kəbənni barà̀ni," kabən baràni!' They said to him, 'We ate your ram.' He says, 'I want my ram! I want my ram!' (Tel. 14)

A narrative tense ${ }^{119}$ has perfective (punctual) aspect. But kāmar would normally express a habitual activity, which is a type of imperfective aspect. So the function in narrative differs in aspect as well as tense from its usual function. There is, however, no present perfective tense available in the language as an alternative.

In another Telkepe recording a different form, "ämor, is used with the same function. This is the unprefixed qãtal form, normally used with irrealis functions, e.g. wishes, purposes etc. The following is an excerpt from this text:

(8) ba'dén kamnatwíli kammatwili, ' 'amri là kyalpat,' mxubéri EDrive ${ }^{\mathrm{E}}$ kamxabránna $\theta e ̀ l a, '$ Then they made me sit, they made me sit. They say, 'You won't learn.' I called 'Drive' [a driving school, I called him, he came ...

The same form is found in the Hamziye text, alternating with the qtalla form (marre):

(9) dàwa w' marra: hòo!' da'watiyee!' 'amra: hà̀, marra: lè 'ātūtun' 'áwò̃ax hàfla.' A wedding party. And she said, 'Hey Wedding party!' They say (lit. it says), 'Yes?' She said, 'Hey! Won't you all come, so we can hold a party?' (Ham. 13)

I1s Comrie (1976: 73 78). Cf. also Givon (2001: 298300 ).

${ }^{119}$ I.e one used for narra ing sequen ial even s. 
(10) marra: hoo!' zumaçiyoo!' 'ấmar: hà??' 'amra: lé 'ātat 'awठax xa- ... dà wa?' She said, 'Hey! Pipe player!' He says, 'Yes?' She says, 'Won't you come so we can make a wedding party?' (Ham. 19)

This form seems to be similar in function to kämar: it is probably used to make the narrative more vivid. It may be that some speakers prefer the use of the irrealis form because it is neutral as to aspect and avoids the awkwardness of using a normally imperfective form in a perfective function. ${ }^{120}$

This appears not to be a problem in Alqosh, where we find the same unprefixed form but with the past suffix -wa: 'ämarwa. This is the qătalwa form and is normally used in Alqosh for one of two functions: past habitual (i.e. imperfective) and past subjunctive (irrealis). ${ }^{121}$ The following are examples of its normal usage:

(11) pälaxwa go alquš. He used to work in Alqosh.

(12) b'ela t pálaxwa. He wanted to work.

Again, with the verb 'to say', this form functions as a narrative tense:

(13) pášla babxầya!. 'ämarwa: 'í, kában kàtwi!' He started crying. He said, 'Oh, I want my thorn!' (Alq. 4)

(14) 'amräwa: là bäxot, 'byäwánnux gyà-pa0əxta.' She said, 'Don't cry! I'll give you a piece of bread.' (Alq. 5)

(15) 'āmarwa: hàlli.' šqálla patẏ̀xta w' pás̆la fyàra.' He said, 'Give it to me.' He took the piece of bread and started flying. (Alq. 6)

If we take it that it is the past habitual function which has been extended to a narrative function, then again we have a normally imperfective form being used for perfective aspect. There is a parallel to this in the modern French Imparfait pittoresque. The French Imparfait normally functions as a past imperfective. It can be used, however, in narrating events, especially in journalistic style, and has the function of making the narrative more vivid. ${ }^{122}$ Comrie (1976: 77-8) views this as an alternative to changing the tense: 'to retain the tense, but shift aspect, for instance to lose aspect distinctions in the past tense, just as if the whole had been shifted into the present, with the typical present aspectual distinctions, or lack of distinctions.' Whatever the reason, the Alqosh "amorwa may have developed in the same way as the French Imparfait pittoresque, even though it is restricted to the verb 'to say'. ${ }^{123}$ Although 'ämorwa

120 Cf. Comrie (1976: 73 37) for a discussion of how in some languages aspec is neu ralized in he nama ive presen, while in o hers he dis inc ion is re ained.

121 In o her dialec s, such as Telkepe, hese are commonly dis inguished by he use of he indica ive prefix $(k)$ on he indica ive form: kämarwa 'he used o say', 'ämarwa 'ha he migh say' (au hor's own da a).

${ }_{122}$ Cf. Rickard (1989: 142) for a descrip ion of he emergence of his usage.

12.3 I should be no ed however ha, unlike 'ämanwa, he Imparfait pittoresque is no used in he spoken language (Rickard 1989: 142). 
is basically a past tense form, its usage in narrative does appear to be related to the narrative present: (i) it is used in the same contexts as true narrative presents kämar and 'amar, and (ii) it is the past tense that is formally similar to the present tense (both being formed from the base qätal). There is however the alternative possibility that it is the irrealis 'ämorwa '(that) he might say' that has been extended to the narrative function. The parallel with French, however, favours the former interpretation.

In the Tazakand text the situation is different again. Mostly the verb to say in narrative is treated the same as any other verb. That is, it is usually formed with the stative participle, with or without the past enclitic copula. There are however some examples of the qtalla form with this verb, as for instance in line 56:

(16) míra: b ála xàti,' ána b nơsi,' He said, 'By God, sister, I am by myself.' (Taz. 56)

Other examples are found in line 23, 37 and 58.

There are also some examples of qtalla with other verbs in line 11, where the old woman recounts what happened to the thorn. But these verbs are not part of the main narrative and so may express a slightly different tense:

(17) tílax púloṭli rüpíli jo tanüra.' 'You came and $\mathbf{I}$ took it out and threw it into the oven.' (Taz. 11)

It may be that qtalla expresses the recent past, ${ }^{124}$ in opposition to qtilalqtílewa which expresses a more remote past. If so, its use with ${ }^{\circ} m r$ I could again be a device to bring the narrative closer to the present.

The question arises of why the verb 'to say' in particular occurs with the historical present or related forms. The historical present has been much investigated for other languages, including colloquial English. In English it is not restricted to the verb 'to say', so no precise parallel can be provided. Nevertheless it does seem to behave differently with this verb. ${ }^{125}$ Schiffrin (1981: 58) links this to the association of 'to say' with direct quotes. According to her, direct quotes 'increase the immediacy of an utterance which occurred in the past by allowing the speaker to perform that talk in its original form, as if it were occurring at the present moment.' Direct quotes are usually preceded by a verb of saying, so she argues, 'Using the present tense with that verb is another way in which the narrative framework replaces the situation of speaking in order to make the reported material more immediate.' The statistics from her corpus show that the historical present is in fact more frequent with direct than indirect quotes.

12 As i does in o her dialec $s$ such as Barwar ( $G$. Khan, personal communica ion).

125 According o Wolfson (1979: 178 9), unlike o her verbs, 'many, indeed mos of he swi ches be ween say and said seem unmo iva ed.' 
How is this relevant to NENA narratives? In these, indirect quotes are rare: almost all quotes are direct. Direct quotation brings the actual words spoken directly to the ears of the audience, as if they were being spoken afresh. This may be a motivation for the verb introducing the quotation to be shifted to the present tense - a motivation that does not exist for other verbs in the narrative.

\subsection{The Indefinite-Specific Article xa-}

Another linguistic device used in narrative is the indefinite article $x a$ - (in some dialects m. $x a-, f .(\dot{g}) \partial a-)$. In NENA this tends to have quite a restricted function. Rather than being used with any indefinite nouns, it usually has an indefinite specific function, i.e. it is used with referents that are indefinite - not known to the listener - but specific. It reflects the difference between 'He wants to marry an Australian', meaning a specific person who happens to be Australian, and the same sentence without the implication that he has any particular Australian in mind. In fact $x a$ - is not even used with all indefinite specific referents, but only with those which are going to have some importance in the ensuing discourse. This is expressed explicitly in standard English as 'a certain'. In colloquial English, the word 'this' is used, as in for example 'At the bus-stop I met this man, right. And we got into conversation and he said ...'

An example of this usage is the first line of all the versions, where the sparrow, the main character of the story, is introduced for the first time with the article $x a$ - The other main characters are also usually introduced in this way, except in Telkepe. Some examples are:

(18) Alqosh

(a) zálla bafyà̀ra, xzéla ġðà-sota.' 'āmarwa: wó sotò!' màplatlo katwi!' $\mathrm{He}$ went flying, he saw an old woman. He said, 'Hey, Granny! Take out my thorn!' (Alq. 2)

(b) féro u fèra u' xzela xá-šiväna bixăla màsta,' 'u làtwäalo làxma.' He flew on and on and saw a shepherd eating yoghurt without having any bread. (Alq. 7)

(19) Hamziye

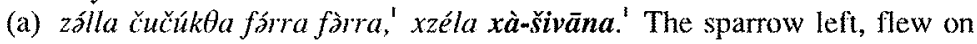
and on, and saw a shepherd. (Ham. 6)

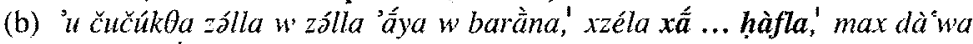
'amraxla.' So the sparrow went on and on, she and the ram, and saw a party, like a wedding party, let's say. (Ham. 12)

(20) Tazakand

(a) xíšta xzíta ina xá-dāy sòta,' pyáya làxma.' She went and she saw, lo and behold there was an old mother, baking bread. (Taz. 4)

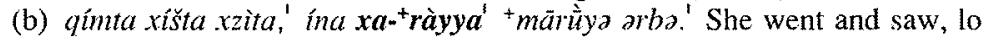
and behold, there was a shepherd grazing sheep. (Taz. 19) 
The things exchanged are also sometimes introduced by the article: in Alqosh the piece of bread and the ram; in Hamziye the thorn, the bread and the ram; in Tazakand the piece of bread, the sheep and the saz.

Naturally the importance of someone or something to the following discourse is relative and subjective. In the Telkepe version only the sparrow is marked by the indefinite article. This is probably a stylistic choice of the individual speaker, rather than a dialectal difference, as in other Telkepe texts the article is more common.

\subsection{Narrative Devices Used to Depict a Scene Vivdly}

There are three narrative devices which are often, but not always, used together. These are (i) a presentative particle, (ii) the deictic copula, and (iii) the

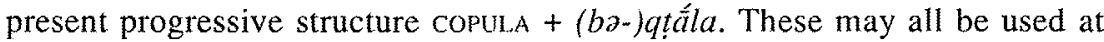
points in the narrative where the speaker wishes to depict a scene vividly.

The presentative particle ina is very common in the Tazakand version, but not found in the other two versions. Ina, in this function, is not easily translatable into normal English, but is similar in function to Hebrew hinneh, conventionally translated as 'behold!' or 'lo!'. Ina is used to present a new scene to the listeners: to draw their attention to something new and often surprising. A more natural translation in English might be 'and right there was a ...' or 'and there before her very eyes was a ...' As one might expect from its function in drawing an image, ina often follows a verb of seeing. We see a typical use of ina in the following lines:

(21) ina hádela čpina, masčina,' +baxlắwola àrba,' Behold, he is so hungry, poor thing, that he is milking the sheep (Taz. 20)

(22) Xíšta xzíta ina:' lítan 'baṣrat qanyànd,' ̀̀rbo,' yonàtə,' qad ná mandiyāna 'ax $x l i$.' She went and saw, behold! There is no meat of cows, or of sheep or pigeons, those things which are eaten. (Taz. 37 8)

We sometimes find ina followed simply by a noun-phrase, presenting a new scene:

(23) xíšta xzíta ina xá däy sòta,' pyấya làxma.' She went and she saw, lo and behold there was an old mother, baking bread. (Taz. 4)

(24) qímta xíšta xzita,' ína xa 'ràyya' 'mầrùỳ arba.' She went and saw: right there was a shepherd grazing sheep. (Taz. 19)

The deictic copula is used in NENA dialects both for physical deixis - 'here he is!' or 'there he is!' - and to express an immediate, contingent present tense: 'he is ... right now'. In line 17 of the Tazakand version we see these functions used to give vividness and immediacy to the scene being depicted:

(25) tamòoo!' wéeela xa bèta,' xa śrba +bráya l pátxat țürra!' Way over there! There is a house, and a sheep grazing at the foot of the mountain. (Taz. 17) 
In the following lines ina is combined with the deictic copula:

(26) xišta xzíta ina wéeela xa 'màta,' yấna jo bi páljọt țüràna,' l áštad dàra.' She went and saw, behold there is a village way over there. I mean, in the middle of the mountains, at the bottom of a valley. (Taz. 36)

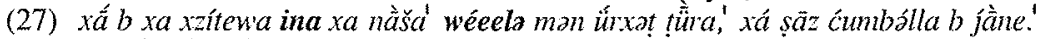
u bxằ̌sa.' bxăšsela,' ... All of a sudden, she saw, behold there is a person (coming) from the mountain pass, a saz slung over himself, going along. $\mathrm{He}$ is going along ... (Taz. 54 55)

The present progressive is also used to give immediacy to a scene, as for

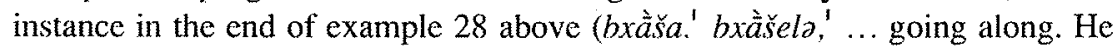
is going along ...). It may also be combined with ina or the deictic copula:

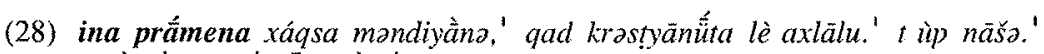
xnı̀̄ro,' čalbo,' süsawà̃ta.' Behold they are slaughtering some things which Christians don't eat. Even humans. Donkeys, dogs, horses. (Taz. 39)

(29) xzítewa wéla tónna +plàta.' $m$ čấwat xa bèta.' She saw there is smoke coming out, from the window of a house. (Taz. 3)

The Alqosh and Telkepe versions lack these devices with one exception, in the Alqosh version, of the present progressive with the deictic copula:

(30) xzelo náša wole tíwo boštăya w' lätte màzzo.' He saw people who are sitting drinking yet they don't have any appetisers. (Alq. 15)

In fact the texts presented here present an incomplete picture of the usage of these devices. In Alqosh, at least, a presentative particle slla, equivalent in function to Tazakand ina, is commonly used in narrative together with the deictic copula wols and the present progressive:

(31) wéra b 'e käwa, xzéla 'alla wóle hilánod 'armònə,' xákma zárṛa 'armòñ,' wolk mparsóno ta gyanc̀y.' He entered through that hole and lo and behold he saw there are some pomegranate trees! some enormous ponegranates which are splitting open of their own accord.

(32) xèra,' 'álla wola kắwa kòmta w' šáklad ó näša kòma x šaxra.' He looked: Io and behold the window is black and the appearance of that man as black as charcoal!

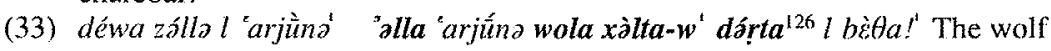
went to the cripple but lo and behold! The cripple has eaten and returned home!

\subsection{Intonation}

In oral story-telling, intonational devices - rises and falls in pitch and loudness, as well as lengthening of syllables - are used to make the story more exciting and vivid, in order to keep the listeners' attention. The texts presented

126 Here he deic ic copula is combined wi h s a ive par iciples o produce a presen perfec. 
above are no exception. It would however be cumbersome to mark all of these devices in the transcription here. What is marked is the nuclear (main) stress () and lesser stresses (), which are important for understanding pragmatic features such as focus. Another device marked is elongated vowel length, where a long vowel is lengthened even further. This is often used in NENA dialects to express distance, most notably in demonstratives such as 'awäha 'that over there', 'awāaha (with elongated vowel) 'that, way over there'. ${ }^{27}$ Vowel lengthening is also used with other deictic words: in Peshabur we find the deictic adverbs tamăha 'over there', tamäăha 'way over there', and the deictic copula hole 'here/there he is', hoole 'there he is way over there'. ${ }^{128}$ The same elongated vowel length is found in the Tazakand version, with the same function. Here it is found with the deictic adverb tamo 'there' and the deictic copula wela 'here/there he is'. This device adds further to the vivid depiction of the scene, as the illusion is created that the speaker herself is actually pointing to the scene. ${ }^{129}$

(34) tamòò !' wéeela xa bèta,' Way over there! There is a house (Taz. 17)

(35) xísta xzíta ina wéeela $x a^{+}$màta, She went and saw, behold there is a village way over there. (Taz. 36)

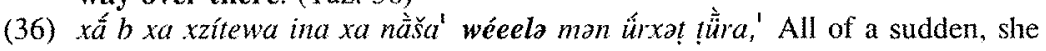
saw, behold there is a person (coming) from the mountain pass (Taz. 54)

It is also common in NENA dialects to lengthen the final syllable of an intonation group, usually in conjunction with either rising or level pitch. This is used for various functions, for instance in joining together items in a list, in yes/no questions, and in calling someone. In two of the texts presented here (Ham. and Taz.), it is also used to express distance or length of time. Specifically, it is used with verbs of motion to emphasize the distance travelled and time that has passed. In this function it is also used in conjunction with repetition (see $\$ 7.7$ below).

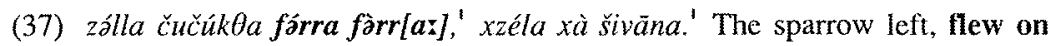
and on, and saw a shepherd. (Ham. 6)

(38) príxta xíšta xišta xdírta xdirtta:z]!' 'rítewa jo țürắnad dùhuk.' She flew (and went) on and on, and wandered around and around then she glanced (?) in the mountains of Dohuk. (Taz. 16)

127 Such forms are a es ed in many dialec s, such as Chris ian 'Aqra, Mangesh, Tin, e c. (au hor's own da a).

${ }_{128}$ See E.J. Coghill (2008) for a discussion of deic ic words in he Chris ian dialec of Peshabur.

129 In many dialecs, including he closely rela ed dialec of Darband (au hor's own da a), cer ain deic ic words such as awó " ha "and tamó 'over here' (and heir leng hened equivalen s) are used only when he speaker can poin o hem (even if hey are no ac ually visible). $O$ her forms (Darband *o, "tama) are used when poin ing is difficul or impossible, for example when he hing referred $o$ is in ano her coun ry or he speaker is alking abou he pas. This is mos likely he case also in Tazakand. 


\subsection{Repetition}

There are three types of repetition found in the texts. One is the repetition of actions and actual words in each successive episode, as is common with folktales. Another quite different type is the repetition of an individual verb several times in succession. This quasi-onomatopoeic device is used to indicate that the activity went on for some time. Used with verbs of motion to depict journeying, it also helps to mark the transitions between episodes. This device is found with both the main narrative tense and with infinitives:

(39) Alqosh

(a) féra-u fèra-u' xzela xá šivãna bixála màsta,' 'u làtwāla làxma.' He flew on and on and saw a shepherd eating yoghurt without having any bread. (Alq. 7)

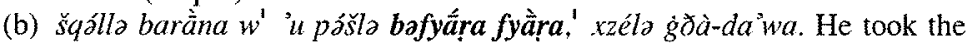
ram and started flying and flying. He saw a wedding party. (Alq. 14)

(40) Hamziye

(a) zálla čučúk $\theta_{a}$ fárra fàrra,' xzéla xà šivāna.' The sparrow left, flew on and on, and saw a shepherd. (Ham. 6)

(b) 'u čučủ $\theta a$ zálla-w zálla 'ấya w baràna,' xzéla xá ... hàfla,' max dà wa 'amraxla.' So the sparrow went on and on, she and the ram, and saw a party, like a wedding party, let's say. (Ham. 12)

(c) zàlla.' fárra forra förra w,' páśla bimāra tìn u' bəzmấra ta gyàna $w . '$ She left. She flew on and on and on, and started saying 'ting' and singing to herself: (Ham. 24)

(41) Tazakand

(a) xíšta xišsta xdirta jrišsta xá yarxa tuxmz̀nta:' āzan šaqlànna ćitwi.'

She went on and on, wandered around, took one month then thought, 'Let me go and get my thorn.' (Taz. 9)

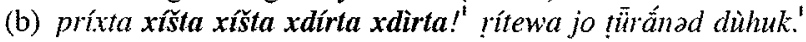

She flew on and on, and wandered around and around then she glanced (?) in the mountains of Dohuk. (Taz. 16)

(c) xíšta màdra,' xdírta xdírta xdirta:' lá āzan šaqlánna làxmi!' She went away again and she wandered around and around and around. 'Let me go and get my bread!' (Taz. 28)

(d) árba, xắti, lübàlta,' muxdárta muxdárta muxdàrta,' The sheep, sister, she took away, and she took it around and around and around. (Taz. 34)

A third type of repetition is a kind of connective repetition, where the last phrase of a short sequence of events is repeated at the beginning of the next sequence of events. Typically the start of the next sequence is also marked by a higher pitch. Connective repetition can be seen in the following three consecutive lines:

(42) Tazakand

(a) ćítwa pülḋttawa' rüpíta jo tanüra.' She took out the thorn and threw it into the oven. (Taz. 7)

(b) rüpitawa jo tanû́ra.' u sipśrta xišta.' She threw it into the oven. And the sparrow went on. (Taz. 8) 
(c) xíšta xíšta xdírta jríšta xá yarxa tuxmànta:" äzan šaqlànna ćitwi.' She went on and on, wandered around, took one month then thought, 'Let me go and get my thorn.' (Taz. 9)

There is also an example in Hamziye:

(43) Hamziye

'u čučủkfa zálla w zálla 'ăya w baràna,' xzéla xấ ... hâfla,' max dắwa 'amraxla.' So the sparrow went on and on, she and the ram, and saw a party, like a wedding party, let's say. (Ham. 12)

(b) dà'wa w' marra: hòo!' da 'wativec!' A wedding party. And she said, 'Hey Wedding party!' (Ham. 13)

This device is not restricted to pure narrative, but can also be found in another type of sequential discourse, that is sequences of events that happened regularly. An example is the following extract from a Telkepe recording, where a woman is talking about the goods that the people of Telkepe used to trade:

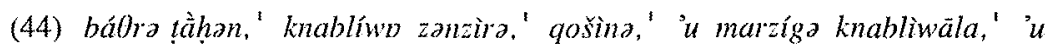
kamzabníwäla byäwad bàgdad.' kamzabniwäla bgäwad bágdad u ba dèn,' «..." pášlan kódux móno ta bàgdad!' kud wá̉lan móno ta bàğdad,'... After tahini, they took starlings, larks, and they took marziga. ${ }^{131}$ And they would sell them in Baghdad. They would sell them in Baghdad and then we started to make preserves for Baghdad. When we made preserves for Baghdad ...

\section{CONCLUDING REMARKS}

There are many similarities between the dialects in the devices they use in narration. Although the main narrative tense varies, especially between Tazakand and the others, there appears to be unity between the dialects in treating the verb 'to say' differently. As regards the devices used to depict scenes more vividly, the dialects exhibit very similar behaviour, even if the precise forms vary.

\section{ACKNOWLEDGEMENTS}

I would like to express my heartfelt thanks to the following: the storytellers: Ghazwan Khundy (Alqosh), Mahir Awraham (Telkepe), Raheel Mansor (Hamziye) and Joan Younan (Tazakand); Narges Pourabdi, for kindly putting me in contact with her aunt, Mrs. Younan, and helping me with the transcription and translation; Nineb Lamassu for invaluable assistance with the transcription and translation of the Telkepe and Tazakand versions; and Amal Marogy for her help with the Hamziye version. All mistakes are of course the author's responsibility.

131. Ano her ype of bird. 


\section{ABBREVIATIONS AND SYMBOLS}

$\begin{array}{ll}\text { A. } & \text { Aramaic } \\ \text { Alq. } & \text { Alqosh } \\ \text { Arab. } & \text { Arabic } \\ \text { fem. } & \text { female } \\ \text { Ham. } & \text { Hamziye } \\ \text { K. } & \text { Kurdish } \\ \text { Pers. } & \text { Persian } \\ \text { Taz. } & \text { Tazakand } \\ \text { Tel. } & \text { Telkepe }\end{array}$

\section{REFERENCES}

Chyе , M. 2003, Kurdish English Dictionary, New Haven, Conn.; London: Yale Uni versity Press.

Cogh L., E.J. 2003, The Neo Aramaic dialect of Alqosh. Unpublished PhD thesis, Uni versity of Cambridge.

2008, 'Some Notable Features in North Eastern Neo Aramaic Dialects of Iraq', in G. Khan (ed.), Neo Aramaic Dialect Studies, Piscataway: Gorgias, pp. 91105.

The Neo Aramaic dialect of Telkepe (forthcoming).

COMR E, B. 1976, Aspect: an introduction to the study of verbal aspect and related problems, Cambridge; New York: Cambridge University Press.

Ferguson, C. A. and R CE, F. A. 1960, 'Iraqi Children's rhymes' in Journal of the Amer ican Oriental Society 80: 4, pp. 335340.

Fox, S.E. 1997, The Neo Aramaic dialect of Jilu, Semitica Viva 16. Wiesbaden: Har rassowitz.

Garbell, I. 1965, 'The Impact of Kurdish and Turkish on the Jewish Neo Aramaic dialect of Persian Azerbaijan and the adjoining regions', Journal of the American Oriental Society 85: 2, pp. 159177.

G von, T. 2001, Syntax: An Introduction, vol. II, revised edition, Amsterdan and Phila delphia: John Benjamins.

HE zRon, R. 1969, 'The Morphology of the Verb in Modem Syriac (Christian Collo quial of Urmi)', Journal of the American Oriental Society 89: 1, pp. 112127.

Khan, G. 1999, A Grammar of Neo Aramaic, Leiden: Brill.

Kro KOFF, G. 1982, A Neo Aramaic dialect of Kurdistan. New Haven: American Orien tal Society.

MaClean, A.J. 1901, A Dictionary of the Dialects of Vernacular Syriac as Spoken by the Eastern Syrians of Kurdistan, North West Persia, and the Plain of Mosul, Oxford: Clarendon Press. Reprinted, Piscataway, NJ: Gorgias Press, 2003.

Op sro, E. 1988, The Sound Systen of Modern Assyrian (Neo Aramaic), Semitica Viva 2. Wiesbaden: Harrassowitz.

Oraham, A. J. 1943, Oraham's Dictionary of the Stabilized and Enriched Assyrian Lan guage and English, Chicago: Consolidated Press (Assyrian Press of America).

Polo SKY, H.J. 1961, 'Studies in Modern Syriac', Journal of Semitic Studies 6, pp. 1 32 (= Collected Papers. Jerusalem 1971, pp. 585 616).

R CKARD, P. 1989, A History of the French Language, $2^{\text {nd }}$ edition, London: Routledge.

SCH FFR N, D. 1981, 'Tense Variation in Narrative', Language 57:1, pp. 4562. 
Wär.chl, B. 2005, Co compounds and Natural Coordination, Oxford: Oxford Univer sity Press.

Wol son, N. 1979, 'The Conversational Historical Present Alternation', Language 55:1, pp. 168182.

YAss N, M. 1977, 'Bi polar Terms of Address in Kuwaiti Arabic', Bulletin of the School of Oriental and African Studies 40(2), pp. 297301.

Younansardaroud, H. 2001, Der neuostaramäische Dialekt von Särdä:rid, Semitica Viva 26. Wiesbaden: Harrassowitz. 